\title{
Synthesis and Evaluation of Biphenyl Derivatives as Potential Downregulators of VEGF Protein Secretion and Telomerase-Related Gene Expressions
}

\author{
María Sánchez-Peris, ${ }^{a}$ Eva Falomir, ${ }^{\mathrm{a}, *}$ Juan Murga, ${ }^{\mathrm{a}, *}$ Miguel Carda, ${ }^{\mathrm{a}} \mathrm{J}$. Alberto Marco ${ }^{\mathrm{b}}$ \\ ${ }^{a}$ Depart. de Q. Inorgánica y Orgánica, Univ. Jaume I, E-12071 Castellón, Spain \\ ${ }^{b}$ Depart. de Q. Orgánica, Univ. de Valencia, E-46100 Burjassot, Valencia, Spain
}

\section{Article history:}

Received

Received in revised form

Accepted

Available online

\section{Keywords:}

Bipehnyl derivatives

Telomerase

VEGF

Antiangiogenesis

hTERT

\begin{abstract}
A group of 47 biphenyl functionalized compounds, prepared by means of Suzuki couplings, has been investigated for their cytotoxicity on two tumoral cell lines (HT-29 and MCF-7) and one non tumoral cell line (HEK-293). 29 selected compounds have been investigated for their ability to inhibit the production of the vascular endothelial growth factor (VEGF). Subsequently, the capacity of the compounds to downregulate the expression of the $V E G F, h-T E R T$ and $c-M y c$ genes, the two latter involved in the control of the activation of telomerase, has also been determined.
\end{abstract}

\section{Introduction}

Thanks to the intense studies on genes that mediate cancer progression and therapeutic resistance, many gene targets that regulate apoptosis, proliferation and cell signaling have been identified. Multiple cumulative genetic and/or epigenetic changes are needed to cause cancer. Molecules that can inhibit expression of such genes are powerful tools in cancer research. ${ }^{1}$ In this sense, methodologies focused on sequence-specific gene suppression strategies involving antisense oligonucleotides and ribozymes or else involving gene silencing using RNA interference (RNAi) have been developed. ${ }^{2}$ However, their adaptation as broadly applicable functional genomic and therapeutic tools has proven difficult because of problems regarding stability and poor efficiency of delivery.

Many experiments have shown that targeting a single gene can inhibit the growth and proliferation of tumor cells. ${ }^{3}$ However, interference targeting a single gene has limitations in the prevention and treatment of cancer. It is known that tumorigenesis results from multiple gene mutation so that therapies targeting multiple genes may have better effects on malignant tumors.

In most solid tumors, angiogenesis is an important process for tumor growth and metastasis. ${ }^{4}$ Many different mediators are involved in this process, including VEGF, which has been shown to play a critical role in pathological angiogenesis. ${ }^{5}$ VEGF levels in serum are tightly associated to a more aggressive disease state and may serve as a marker to evaluate diagnosis. Blocking VEGF expression can inhibit tumor growth and prevent metastasis. ${ }^{6}$

Most cancer cells also exhibit telomerase activity. The latter maintains the length of the telomeres, thus preserving genomic stability. ${ }^{7}$ Telomerase is a ribonucleoprotein composed of two main subunits: the human telomerase RNA (hTR) and the human telomerase protein (hTERT). Many studies have demonstrated that interference of $h T E R T$ gene expression can efficiently inhibit the growth and tumorigenicity of cancer cells. ${ }^{8}$ hTERT gene is a rate-limiting factor in telomerase synthesis and activity.

The c-myc gene is amplified in various human cancers, including lung carcinoma, ${ }^{9}$ breast carcinoma $^{10}$ and colon carcinoma. ${ }^{11}$ The c-myc protein is a transcriptional factor with an important role in cell proliferation, differentiation, invasion and adhesion of tumor cells. ${ }^{12}$ It is also involved in the activation of hTERT gene transcription.

The VEGF, hTERT and $c-M y c$ genes therefore may be good targets for the development of a new drug with better therapeutic effect on malignant tumor. ${ }^{13}$

Molecules containing biaryl moieties are relatively common within natural products. For their preparation, Nature has developed an ample array of biosynthetic strategies. ${ }^{14}$ A number of these biaryl natural products belong to the biogenetic class of lignans. ${ }^{15}$ Two of these, honokiol and magnolol (Figure 1), have aroused a great degree of interest because of their various pharmacological properties. These products and many derivatives thereof, both of natural and synthetic origin, have been reported to display antioxidative, anti-inflammatory, anti-tumor, antidiabetic, anti-microbial, anti-neurodegenerative, anti-depressant, pain control, gastrointestinal, cardiovascular and liver protective properties, among others. ${ }^{16,17}$
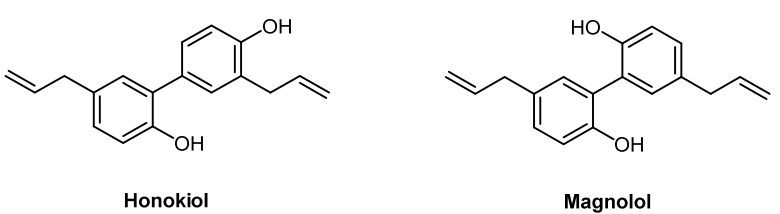

Figure 1. Structure of honokiol and magnolol. 
During the last years, we have been investigating a range of analogs of natural products ${ }^{18}$ for their cytotoxicity and potential value in anticancer therapy. ${ }^{19}$ The latter feature may be related to the ability of the compounds to disrupt microtubule dynamics, ${ }^{20}$ to inhibit the angiogenesis process ${ }^{21}$ or to perturb the activation of telomerase $\mathrm{e}^{22}$ among other alternative mechanisms. Since the natural biphenyl derivatives honokiol and magnolol display valuable anticancer activity, we decided to prepare a number of synthetic biphenyl derivatives (structures depicted in Figure 2), and to investigate their behavior in each of the aforementioned three types of biological activities. Small molecules have always aroused interest in cancer therapy ${ }^{23}$ so that most of our synthetic biphenyl derivatives can be viewed as simplified analogs of honokiol and magnolol, where the two allyl residues have been removed and one or both $\mathrm{OH}$ groups have been replaced by $\mathrm{OMe}$ or $\mathrm{NH}_{2}$ groups. Even with this structural simplification, the retained biphenyl moiety can be still considered a privileged structure $^{24}$ that may prove useful in the development of lead compounds.

\section{Chemical results}

The preparation of biphenyl derivatives can be performed by means of a plethora of methods. ${ }^{25,26}$ Among them, the Suzuki coupling ${ }^{27}$ has become the method of choice in a high number of cases and, indeed, this is the method we have used here for the preparation of compounds 1-47. Our syntheses rely on the coupling of commercial phenylboronic acids with commercial brominated phenols, anilines or anisols under palladium catalysis. Four experimental conditions were applied as detailed below in Scheme 1. The majority of the compounds was synthesized by using conditions $\mathrm{A} .{ }^{28}$ Some compounds, however, were reluctant to preparation under conditions $\mathrm{A}$, in which $\mathrm{PdCl}_{2}$ (dppf) $\cdot \mathrm{CH}_{2} \mathrm{Cl}_{2}$ was employed as the catalyst. In these cases, $\mathrm{Pd}(\mathrm{OAc})_{2}$ was used as catalyst under several conditions (heating at $35^{\circ} \mathrm{C}$, as in the synthesis of $9,{ }^{29}$ heating at $70^{\circ} \mathrm{C}$, as in the synthesis of 11, 20 and $\mathbf{2 6},{ }^{29}$ and heating under microwave irradiation $^{30}$ used in the preparation of amino hydroxyl biphenyls 14, 17 and 19). For experimental details see Material and Methods section.

\section{Biological results}

\subsection{Inhibition of cell proliferation}

Cytotoxic of compounds 1-47 was measured by means of their $\mathrm{IC}_{50}$ values towards the tumoral cell lines HT-29 and MCF-7 and towards the non-tumoral cell line HEK-293. We have also evaluated the therapeutic safety margin of each compound as expressed by means of the $\alpha$ and $\beta$ coefficients. These are obtained by dividing the $\mathrm{IC}_{50}$ value of each compound for the non tumoral HEK-293 line by those for the HT-29 $(\alpha)$ and the MCF-7 ( $\beta$ ) tumoral cell line, respectively (see footnote in Table 1). The higher the value of either coefficient, the higher the therapeutic safety margin for the corresponding compound.

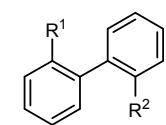

$1 \mathrm{R}^{1}=\mathrm{OH} \quad \mathrm{R}^{2}=\mathrm{H}$ $2 \mathrm{R}^{1}=\mathrm{OMe} \mathrm{R}^{2}=\mathrm{H}$ $3 \mathrm{R}^{1}=\mathrm{OH} \quad \mathrm{R}^{2}=\mathrm{OH}$ $4 R^{1}=O H \quad R^{2}=O H$ $\mathrm{R}^{2}=\mathrm{OM}$ $5 \mathrm{R}^{1}=\mathrm{NH}_{2} \quad \mathrm{R}^{2}=\mathrm{H}$ $6 \mathrm{R}^{1}=\mathrm{NH}_{2} \quad \mathrm{R}^{2}=\mathrm{OH}$

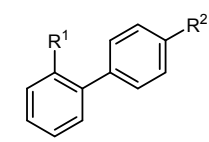

$18 \mathrm{R}^{1}=\mathrm{H} \quad \mathrm{R}^{2}=\mathrm{OH}$ $19 \mathrm{R}^{1}=\mathrm{H} \quad \mathrm{R}^{2}=\mathrm{OMe}$ $20 \mathrm{R}^{1}=\mathrm{OH} \quad \mathrm{R}^{2}=\mathrm{OH}$ $21 \mathrm{R}^{1}=\mathrm{OH} \quad \mathrm{R}^{2}=\mathrm{OM}$ $22 \mathrm{R}^{1}=\mathrm{OMe} \mathrm{R}^{2}=\mathrm{OH}$ $23 \mathrm{R}^{1}=\mathrm{H} \quad \mathrm{R}^{2}=\mathrm{NH}_{2}$ $\begin{array}{ll}24 \mathrm{R}^{1}=\mathrm{OH} & \mathrm{R}^{2}=\mathrm{NH}_{2} \\ 25 \mathrm{R}^{1}=\mathrm{NH}_{2} & \mathrm{R}^{2}=\mathrm{OH}\end{array}$

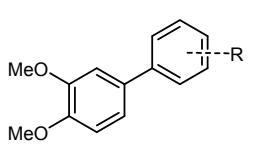

$41 \mathrm{R}=\mathrm{H} \quad 45 \mathrm{R}=0-\mathrm{NH}_{2}$ $42 \mathrm{R}=0-\mathrm{OH} \quad 46 \mathrm{R}=m-\mathrm{NH}_{2}$ $43 \mathrm{R}=m-\mathrm{OH} 47 \mathrm{R}=p-\mathrm{NH}_{2}$ $44 \mathrm{R}=p-\mathrm{OH}$

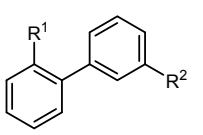

$7 \mathrm{R}^{1}=\mathrm{H} \quad \mathrm{R}^{2}=\mathrm{OH}$ $8 \mathrm{R}^{1}=\mathrm{H} \quad \mathrm{R}^{2}=\mathrm{OMe}$ $9 \mathrm{R}^{1}=\mathrm{OH} \quad \mathrm{R}^{2}=\mathrm{OH}$ $10 \mathrm{R}^{1}=\mathrm{OH} \quad \mathrm{R}^{2}=\mathrm{OMe}$ $11 \mathrm{R}^{1}=\mathrm{OMe} \mathrm{R}^{2}=\mathrm{OH}$ $\begin{array}{ll}11 \mathrm{R}^{1}=\mathrm{OMe} & \mathrm{R}^{2}=\mathrm{OH} \\ 12 \mathrm{R}^{1}=\mathrm{H} & \mathrm{R}^{2}=\mathrm{NH}_{2}\end{array}$ $13 \mathrm{R}^{1}=\mathrm{OH} \quad \mathrm{R}^{2}=\mathrm{NH}_{2}$ $14 \mathrm{R}^{1}=\mathrm{NH}_{2} \quad \mathrm{R}^{2}=\mathrm{OH}$

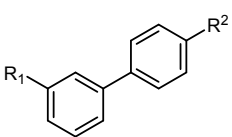

$26 \mathrm{R}^{1}=\mathrm{OH} \quad \mathrm{R}^{2}=\mathrm{OH}$ $27 \mathrm{R}^{1}=\mathrm{OH} \quad \mathrm{R}^{2}=\mathrm{OMe}$ $28 \mathrm{R}^{1}=\mathrm{OMe} \mathrm{R}^{2}=\mathrm{OH}$ $29 \mathrm{R}^{1}=\mathrm{OH} \quad \mathrm{R}^{2}=\mathrm{NH}_{2}$ $30 \mathrm{R}^{1}=\mathrm{NH}_{2} \quad \mathrm{R}^{2}=\mathrm{OH}$ $\mathrm{R}^{1}=\mathrm{NH}_{2} \mathrm{R}^{2}=\mathrm{OH}$

Figure 2. Structures of biphenyl derivatives investigated in this study.

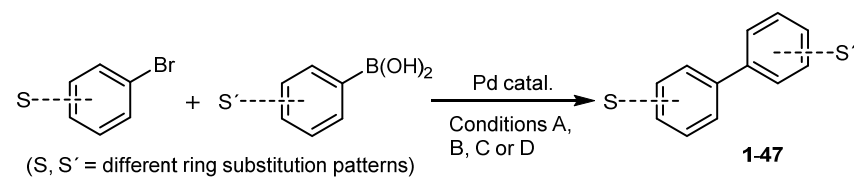

Scheme 1. Synthesis of biphenyl derivatives 1-47. Reagents and conditions: A: $\mathrm{PdCl}_{2}(\mathrm{dppf}) \cdot \mathrm{CH}_{2} \mathrm{Cl}_{2}, 2 \mathrm{M} \mathrm{Na} \mathrm{CO}_{3}$, DME, reflux, 15-18 h. B: $\mathrm{Pd}(\mathrm{OAc})_{2}$, $\mathrm{Na}_{2} \mathrm{CO}_{3}$, ethanol/water (1:1), MW, $150^{\circ} \mathrm{C}, 1 \mathrm{~h}$. C: $\mathrm{Pd}(\mathrm{OAc})_{2}, \mathrm{Na}_{2} \mathrm{CO}_{3}$, ethanol/water $(1: 1), 70^{\circ} \mathrm{C}, 4$ h. D: $\mathrm{Pd}(\mathrm{OAc})_{2}, \mathrm{Na}_{2} \mathrm{CO}_{3}$, acetone/water (1:1), $35^{\circ} \mathrm{C}$, 4h. Acronyms: $\mathrm{DME}=1,2$-dimethoxyethane, $\operatorname{dppf}=1,1^{\prime}$ bis(diphenylphosphino)ferrocene.

The observed $\mathrm{IC}_{50}$ values are in the low to medium micromolar range. In general terms, these biphenyl derivatives were more cytotoxic towards the HT-29 line than towards the MCF-7 line. Indeed, only compounds $\mathbf{2}$ and $\mathbf{5}$ were more cytotoxic than honokiol towards the latter cell line. In contrast, compounds 3, 4, 8, 9, 15, 20, 26, 30, 40, 46 and 47 exhibited lower IC $_{50}$ values than honokiol on the HT-29 line. Furthermore, these compounds also exhibited a markedly higher therapeutic margin than honokiol, with $\alpha$ coefficients being above 5 .

Biphenyl derivatives with lower $\mathrm{IC}_{50}$ values than honokiol for the HT-29 line, or else with higher $\alpha$-coefficients, were selected for the subsequent biological evaluations. The list included the following compounds: $3,4,5,8,9,11,14,15,16,18,20,26,28$, $30,35,37,40,44,45,46$ and 47. 
Table 1. $\mathrm{IC}_{50}$ values $(\mu \mathrm{g} / \mathrm{mL})$ and selectivity coefficients for biphenyl derivatives $\mathbf{1 - 4 7}$.

\begin{tabular}{|c|c|c|c|c|c|}
\hline Compound & HEK-293 & HT-29 & MCF-7 & $\alpha^{b}$ & $\beta^{\mathrm{c}}$ \\
\hline Honokiol & $9.3 \pm 1.6$ & $6.1 \pm 0.5$ & $5.0 \pm 0.7$ & 1.5 & 1.9 \\
\hline 1 & $31.4 \pm 1.6$ & $55 \pm 11$ & $51 \pm 5$ & 0.6 & 0.6 \\
\hline 2 & $52 \pm 3$ & $51 \pm 12$ & $1.6 \pm 0.2$ & 1.0 & 33 \\
\hline 3 & $57 \pm 8$ & $2.5 \pm 0.2$ & $60 \pm 6$ & 23 & 1.0 \\
\hline 4 & $54 \pm 6$ & $2.7 \pm 1.1$ & $>100$ & 20 & $<0.5$ \\
\hline 5 & $54.9 \pm 2.4$ & $16 \pm 5$ & $2.9 \pm 0.5$ & 3.3 & 19 \\
\hline 6 & $54.1 \pm 1.8$ & $44 \pm 8$ & $56.0 \pm 1.6$ & 1.2 & 1.0 \\
\hline 7 & $25 \pm 5$ & $28.0 \pm 0.6$ & $27.4 \pm 2.0$ & 0.9 & 0.9 \\
\hline 8 & $5.5 \pm 1.3$ & $1.1 \pm 0.5$ & $47 \pm 3$ & 5.1 & 0.1 \\
\hline 9 & $>100$ & $5.2 \pm 0.2$ & $>100$ & $>19$ & 1 \\
\hline 10 & $39 \pm 4$ & $35 \pm 7$ & $43 \pm 3$ & 1.1 & 0.9 \\
\hline 11 & $50 \pm 8$ & $22 \pm 4$ & $44 \pm 5$ & 2.3 & 1.1 \\
\hline 12 & $54 \pm 12$ & $42 \pm 7$ & $60 \pm 5$ & 1.3 & 0.9 \\
\hline 13 & $47 \pm 5$ & $49 \pm 5$ & $28 \pm 7$ & 1.0 & 1.7 \\
\hline 14 & $10.5 \pm 0.5$ & $9.2 \pm 1.8$ & $16 \pm 3$ & 1.1 & 0.7 \\
\hline 15 & $68 \pm 11$ & $2.5 \pm 1.2$ & $51.6 \pm 0.4$ & 28 & 1.3 \\
\hline 16 & $34 \pm 10$ & $16.0 \pm 1.9$ & $33 \pm 6$ & 2 & 1.0 \\
\hline 17 & $50.1 \pm 1.6$ & $54 \pm 6$ & $99 \pm 8$ & 0.9 & 0.5 \\
\hline 18 & $45 \pm 6$ & $25 \pm 3$ & $47 \pm 3$ & 2 & 1.0 \\
\hline 19 & $17 \pm 6$ & $45 \pm 8$ & $>100$ & 0.4 & $<0.2$ \\
\hline 20 & $54 \pm 4$ & $1.4 \pm 0.2$ & $>100$ & 38 & $>0.5$ \\
\hline 21 & $44 \pm 8$ & $47 \pm 8$ & $42 \pm 5$ & 0.9 & 1.0 \\
\hline 22 & $44 \pm 5$ & $49 \pm 6$ & $55 \pm 6$ & 0.9 & 0.8 \\
\hline 23 & $>100$ & $>100$ & $1.4 \pm 0.2$ & 1.0 & $>69$ \\
\hline 24 & $31 \pm 8$ & $27.3 \pm 0.4$ & $52 \pm 4$ & 1.2 & 0.6 \\
\hline 25 & $50 \pm 6$ & $51 \pm 8$ & $44.3 \pm 1.0$ & 1.0 & 1.1 \\
\hline 26 & $31 \pm 6$ & $3.4 \pm 1.2$ & $>100$ & 9.0 & 9 \\
\hline 27 & $14.6 \pm 2.4$ & $72 \pm 8$ & $48 \pm 5$ & 0.2 & 0.3 \\
\hline 28 & $35 \pm 10$ & $24 \pm 6$ & $41 \pm 4$ & 1.5 & 0.9 \\
\hline 29 & $55 \pm 7$ & $49.3 \pm 0.2$ & $>100$ & 1.1 & $<0.6$ \\
\hline 30 & $>100$ & $5.4 \pm 1.4$ & $6.5 \pm 0.6$ & $>18$ & $>15$ \\
\hline 31 & $5.1 \pm 2.2$ & $13.9 \pm 2.3$ & $17.8 \pm 0.2$ & 0.4 & 0.3 \\
\hline 32 & $2.0 \pm 0.7$ & $>100$ & $53 \pm 5$ & $<0.02$ & 0.04 \\
\hline 33 & $62 \pm 11$ & $56 \pm 4$ & $49.9 \pm 0.8$ & 1.1 & 1.2 \\
\hline 34 & $27 \pm 3$ & $55.2 \pm 1.6$ & $>100$ & 0.5 & $<0.3$ \\
\hline 35 & $>100$ & $33.7 \pm 1.5$ & $>100$ & $>3$ & 1 \\
\hline 36 & $28 \pm 5$ & $54 \pm 7$ & $50.2 \pm 1.6$ & 0.5 & 0.6 \\
\hline 37 & $>100$ & $21 \pm 4$ & $47 \pm 5$ & $>5$ & $>2$ \\
\hline 38 & $>100$ & $56 \pm 4$ & $56 \pm 4$ & $>2$ & $>2$ \\
\hline 39 & $29.2 \pm 1.4$ & $49 \pm 4$ & $>100$ & 0.6 & $<0.3$ \\
\hline 40 & $22 \pm 5$ & $2.2 \pm 0.2$ & $>100$ & 10 & $<0.2$ \\
\hline 41 & $26 \pm 8$ & $41 \pm 3$ & $45 \pm 10$ & 0.6 & 0.6 \\
\hline 42 & $23 \pm 10$ & $>100$ & $55 \pm 5$ & $<0.2$ & 0.4 \\
\hline 43 & $23.1 \pm 0.6$ & $29 \pm 8$ & $48 \pm 3$ & 0.8 & 0.5 \\
\hline 44 & $>100$ & $26 \pm 8$ & $34 \pm 9$ & $>4$ & $>3$ \\
\hline
\end{tabular}

\begin{tabular}{llllll}
45 & $49.9 \pm 1.2$ & $15 \pm 5$ & $18 \pm 9$ & 3.3 & 3 \\
46 & $20 \pm 3$ & $4.0 \pm 1.6$ & $>100$ & 5 & $<0.2$ \\
47 & $23 \pm 4$ & $2.0 \pm 0.7$ & $5.5 \pm 0.8$ & 12.0 & 4 \\
\hline
\end{tabular}

${ }^{\mathrm{a}} \mathrm{IC}_{50}$ values are expressed as the compound concentration $(\mu \mathrm{g} / \mathrm{mL})$ that causes $50 \%$ inhibition of cell growth. The values are the average $( \pm$ s.d. $)$ of three different measurements performed as described in the Material and Methods section. ${ }^{b} \alpha=\mathrm{IC}_{50}$ (HEK-293) / IC 50 (HT-29). ${ }^{\mathrm{c}} \beta=\mathrm{IC}_{50}(\mathrm{HEK}-293) /$ $\mathrm{IC}_{50}(\mathrm{MCF}-7)$. Values of $\alpha$ and $\beta$ have been rounded off to a decimal figure.

\subsection{Effect of biphenyl derivatives on VEGFA protein secretion and VEGF gene inhibition on HT-29 cell line}

The influence of biphenyl derivatives on the expression and secretion of the VEGFA protein was performed on the HT-29 cell line. Twenty-one selected biphenyl derivatives were tested at concentrations that were close to the $\mathrm{IC}_{50}$ values on this cell line (see Table 2). As compound $\mathbf{8}$ exhibited no activity at a concentration below its $\operatorname{IC}_{50}(1.1 \mu \mathrm{g} / \mathrm{mL})$ it was tested at $5 \mu \mathrm{g} / \mathrm{mL}$ On the contrary, as compound $\mathbf{1 4}$ was very active, we deemed more appropriate to conduct the tests at the same concentration as in most of the other compounds. All the results were normalized according to the number of living cells.

Table 2. Concentrations for testing selected compound.

\begin{tabular}{|c|c|}
\hline Concentration & Biphenyl Derivatives \\
\hline $3 \mu \mathrm{g} / \mathrm{mL}$ & $3,4,9,14,15,20,26,30,40,46,47$ \\
\hline $5 \mu \mathrm{g} / \mathrm{mL}$ & Honokiol, 8 \\
\hline $10 \mu \mathrm{g} / \mathrm{mL}$ & 16 \\
\hline $15 \mu \mathrm{g} / \mathrm{mL}$ & $5,11,28,37,45$ \\
\hline $20 \mu \mathrm{g} / \mathrm{mL}$ & 18,44 \\
\hline $30 \mu \mathrm{g} / \mathrm{mL}$ & 35 \\
\hline
\end{tabular}

The amount of VEGFA protein was first determined by means of the ELISA procedure ${ }^{31}$ as described in the Material and Methods Section. Figure 3 shows the percentage of VEGFA secreted to the culture medium after $72 \mathrm{~h}$ of incubation in the presence of each of the selected compounds at the concentrations showed in Table 2. The value observed when cells were treated only with DMSO were used as the control value (standardized to $100 \%)$.

About one half of the studied derivatives showed an ability to downregulate the secretion of VEGFA protein higher than that exhibited by honokiol. Most particularly, compounds 4, 11, 16 and $\mathbf{3 5}$ were able to inhibit the VEGFA protein secretion to about $30 \%$ of the control value. All these four most active derivatives exhibited one hydroxyl and, at least, one methoxyl group in different rings. Besides, the preferred substitution patterns were ortho-ortho, meta-meta or ortho-meta (see Figure 5).

In order to find out whether the selected biphenyl derivatives were able to downregulate the secretion of VEGFA protein by means of interference at the transcriptional level, we tested the ability of our compounds to inhibit the expression of the VEGFA gene. In this case, HT-29 cells were incubated for $48 \mathrm{~h}$ with the selected derivatives at the concentrations showed in Table 2, as well as with DMSO as the control test. The real time quantitative PCR (RT-qPCR) methodology ${ }^{32}$ was then used as described in the Material and Methods Section to determine the percentage of $V E G F A$ gene expression related to control test (see Figure 4). 


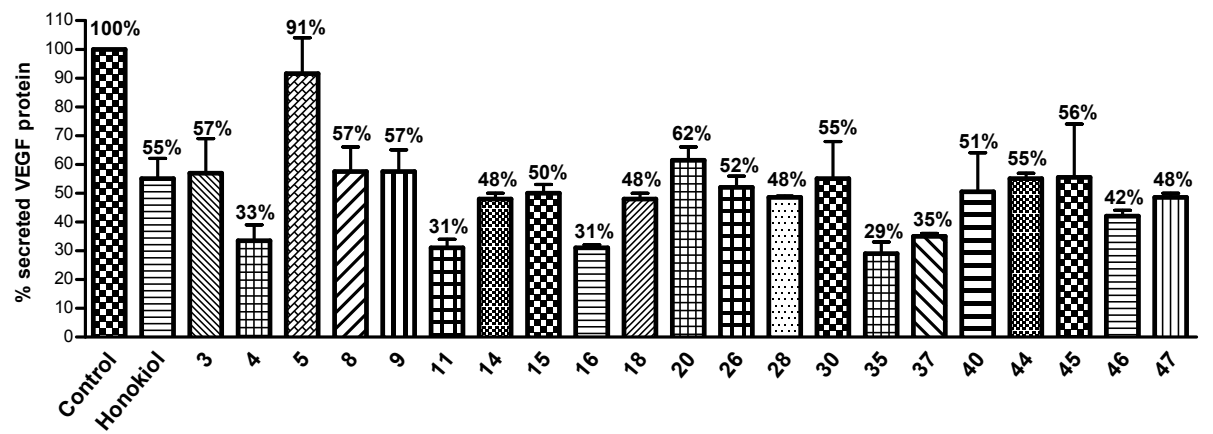

Figure 3. VEGFA protein secretion from HT-29 cells as determined by means of the ELISA procedure. At least three measurements were performed in each case. Bars represent mean values of VEGFA secretion (percentage values related to control) and error bars indicate standard errors of the mean. The statistical analysis was evaluated using one-way ANOVA with Dunnett's Multiple Comparison Test $(\mathrm{P}<0.001)$

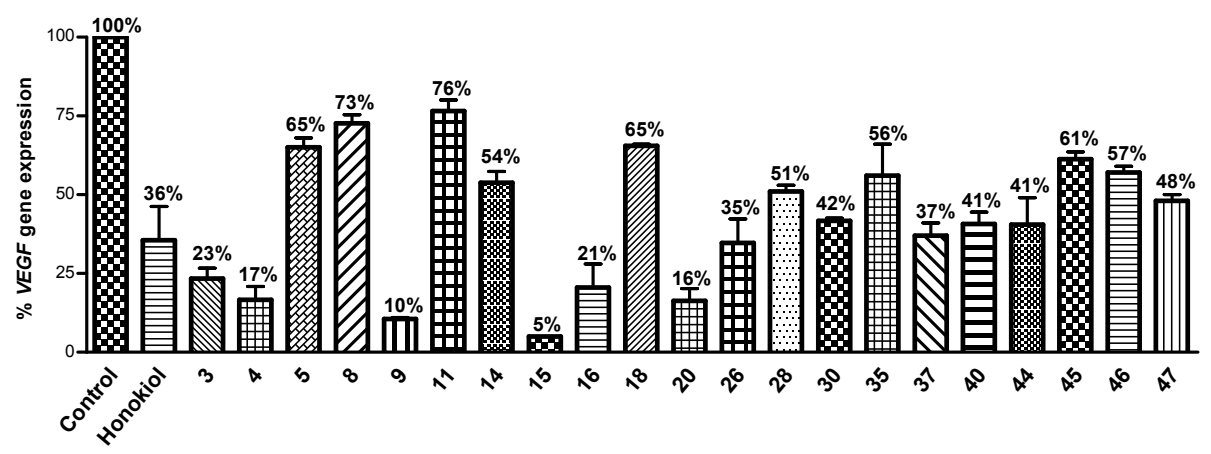

Figure 4. Expression percentage of the VEGFA gene after $48 \mathrm{~h}$ of incubation of HT-29 cells determined by means of the RT-qPCR methodology. At least three measurements were performed in each case. Error bars indicate standard errors of the mean. The statistical analysis was evaluated using one-way ANOVA with Dunnett's Multiple Comparison Test $(\mathrm{P}<0.001)$.

Compounds 3, 4, 9, 15, 16, 20 and 26 were more effective than honokiol in inhibiting the expression of the $V E G F A$ gene. These compounds were able to decrease the VEGFA gene expression to about $20 \%$ or less of the control value (DMSO). The most active derivative was $\mathbf{1 5}$, which inhibited gene expression to $5 \%$ of the control value.

Figure 5 depicts the structures of the compounds showing the highest ability to inhibit (a) VEGFA secretion, and (b) VEGFA gene expression. Compounds $\mathbf{4}$ and $\mathbf{1 6}$ are able to cause strong inhibition of both protein secretion and gene expression (to about $30 \%$ and $20 \%$ of the control, respectively). We can observe that the most active structures in inhibiting VEGFA protein secretion display one hydroxyl and at least one methoxyl group in different rings, whereas the most active ones in inhibiting VEGFA gene expression contain one hydroxyl group in each aromatic ring.

The results discussed above do not show a good correlation between the VEGFA protein amount excreted to the medium and the degree of VEGFA gene expression. This suggests that these compounds possibly exert the control of VEGFA protein production at a phase different from that of gene transcription. ${ }^{33}$

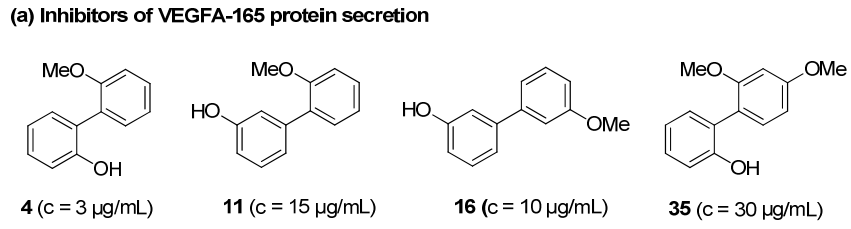

(b) Inhibitors of VEGFA gene expression
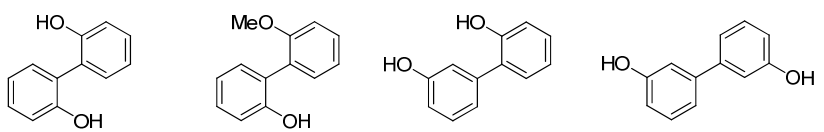

$3(\mathrm{c}=3 \mu \mathrm{g} / \mathrm{mL})$

$4(\mathrm{c}=3 \mu \mathrm{g} / \mathrm{mL})$

$9(\mathrm{c}=3 \mu \mathrm{g} / \mathrm{mL})$ $15(\mathrm{c}=3 \mu \mathrm{g} / \mathrm{mL})$
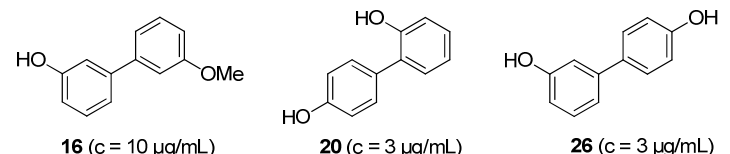

Figure 5. (a) Most active biphenyl derivatives in inhibiting VEGFA protein secretion from HT-29 cell line; (b) Most active biphenyl derivatives in inhibiting VEGFA gene expression from HT-29 cell line. 


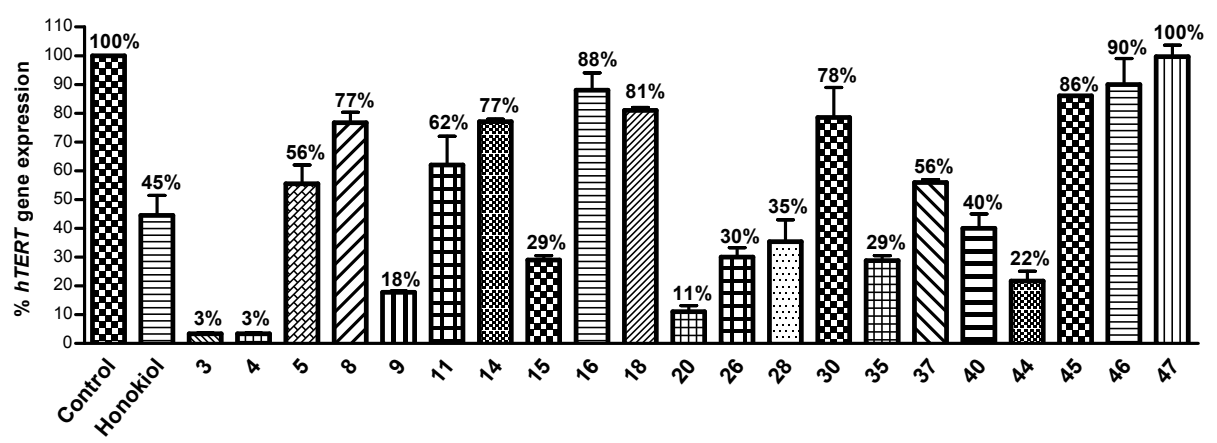

Figure 6. Expression percentage of the $h T E R T$ gene after $48 \mathrm{~h}$ of incubation as determined by means of the RT-qPCR methodology. At least three measurements were performed in each case. Error bars indicate standard errors of the mean. The statistical analysis was evaluated using one-way ANOVA with Dunnett's Multiple Comparison Test $(\mathrm{P}<0.001)$.

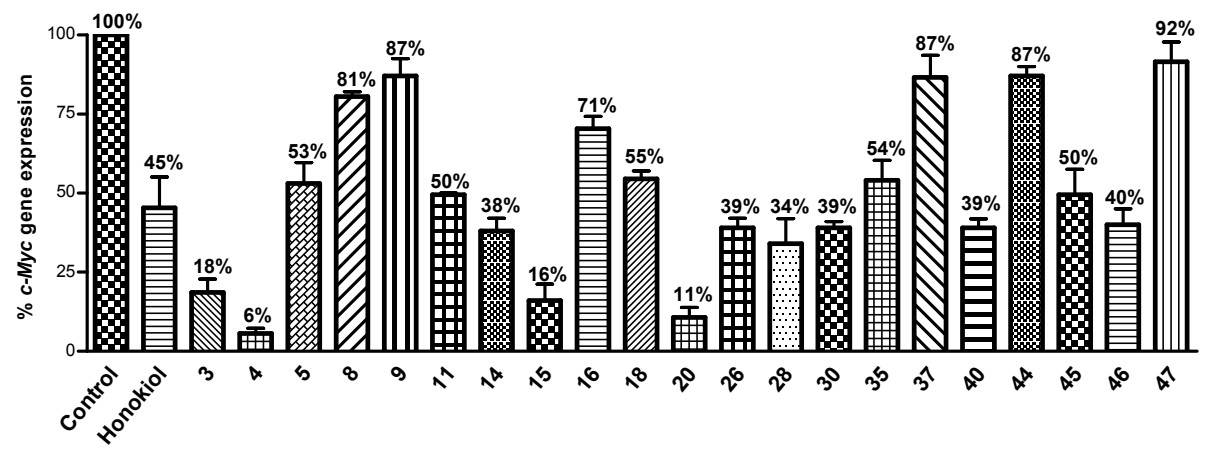

Figure 7. Expression percentage of the $c-M y c$ gene after $48 \mathrm{~h}$ of incubation as determined by means of the RT-qPCR methodology. At least three measurements were performed in each case. Error bars indicate standard errors of the mean. The statistical analysis was evaluated using one-way ANOVA with Dunnett's Multiple Comparison Test $(\mathrm{P}<0.001)$.

\subsection{Effect of biphenyl derivatives on the inhibition of the hTERT and c-Myc genes}

In order to determine whether the studied compounds were able to downregulate the expression of the hTERT and $c-M y c$ genes, we have performed an RT-qPCR analysis on HT-29 tumoral cells. The cells were incubated for $48 \mathrm{~h}$ in the presence of DMSO (control) and in the presence of the selected compounds (see Table 2). Figures 6 and 7 show the results obtained, for the expression of the hTERT and $c-M y c$ genes, respectively.

Biphenyl derivatives 3, 4, 9, 15, 20, 26, 28, 35, 40 and 44 were more active than honokiol in inhibiting hTERT gene expression. The most active compounds were $\mathbf{3}, \mathbf{4}$ and $\mathbf{2 0}$, which decreased the expression of the gene to $3 \%, 3 \%$ and $11 \%$, respectively, of the control value.

As regards the downregulation of the expression of the $c-M y c$ gene (Figure 7), compounds 3, 4, 14, 15, 20, 26, 28, 30, 40 and 46 turned out to be more active than honokiol. Here, compounds 3, 4, 15 and 20 were able to inhibit $c-M y c$ gene expression to less than $20 \%$ of control value. Moreover, compounds $\mathbf{4}$ and 20 were again very active, with gene expression reduced to $6 \%$ and $11 \%$ of the control, respectively.

Figure 8(a) shows the structures of compounds that are able to inhibit simultaneously the expressions of both $h T E R T$ and $c-M y c$ genes. These structures display one hydroxyl group in each aromatic ring or else one hydroxyl and one methoxyl group in different rings. The preferred substitution patterns are orthoortho, meta-meta, ortho-para and meta-para.
Figure 8(b) and 8(c) show the structures of the compounds that are able to inhibit either the hTERT or the $c-M y c$ gen expressions, respectively. It is worth noting that the presence of an amine group gives rise to an increase of the inhibitory activity on the $c-M y c$ gene.

\subsection{Conclusions}

We have synthetized forty-seven biphenyl derivatives related to honokiol. The cytotoxicity of the synthetic compounds was tested on HT-29, MCF-7 and HEK-293 cell lines. Although $\mathrm{IC}_{50}$ values of these derivatives were in the low-medium micromolar range, twenty-one of them exhibited higher therapeutic margin than honokiol (see table 1). Table 3 summarizes the results observed for the five most active compounds in all the tested biological properties. Interestingly, these SAR studies showed that all most active biphenyl derivatives exhibit only two oxygenated functions, either two hydroxyls or one hydroxyl and one methoxyl, placed in different aromatic rings. Neither allyl or allyloxy nor amine groups improved the activity of the derivatives (see figure 9). Moreover the preferred substitution patterns for these both oxygenated groups are ortho- ortho and ortho-para. That would be due to the fact that these compounds are more rigid and could be blocked in the most active conformation to join their targets. It is very interesting to point out that these preferred substitution pattern in the biphenyl unit is the same as it is found in natural products honokiol (ortho-para) and magnolol (ortho- ortho). 
It is worth mentioning that compound $\mathbf{4}$ is the most promising as a multiple-gene targeting therapeutic agent because it is able to simultaneously block VEGF secretion and inhibit VEGF, $h T E R T$ and $c-M y c$ gene expressions. Moreover, compound 4 works efficiently at a concentration in the low micromolar range and exhibits a good therapeutic margin.

(a) Compounds with the highest activity in inhibiting both $h T E R T$ and $c-M y c$ gen expression
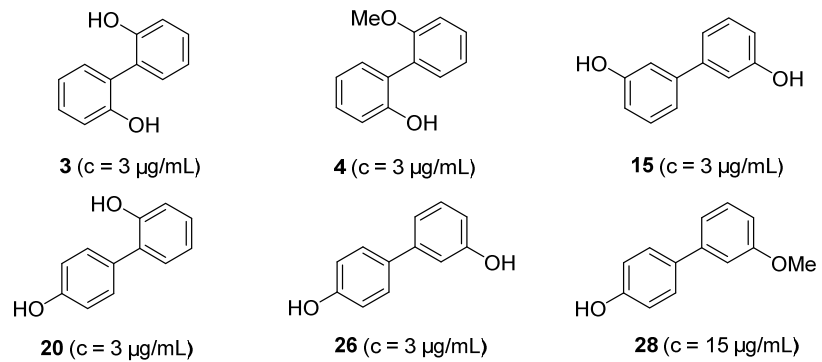

(b) Compounds with the highest activity in inhibiting $h T E R T$ gen expression
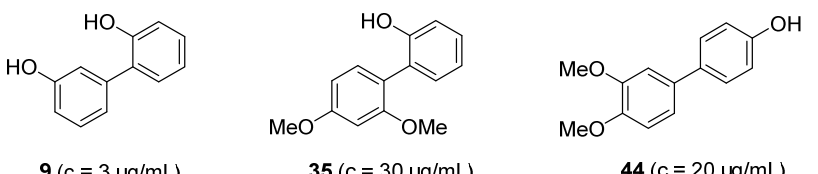

$9(\mathrm{c}=3 \mu \mathrm{g} / \mathrm{mL})$

$35(\mathrm{c}=30 \mu \mathrm{g} / \mathrm{mL})$

(c) Compounds with the highest activity in inhibiting c-Myc gen expression

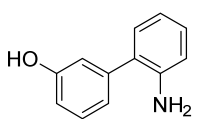

$14(\mathrm{c}=3 \mu \mathrm{g} / \mathrm{mL})$

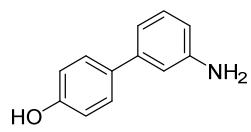

$30(\mathrm{c}=3 \mu \mathrm{g} / \mathrm{mL})$

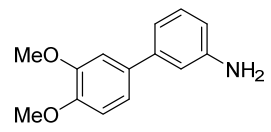

$46(\mathrm{c}=3 \mu \mathrm{g} / \mathrm{mL})$

Figure 8. (a) Most active biphenyl derivatives in simultaneously inhibiting hTERT and $c-M y c$ gene expressions from HT-29 cell line; (b) Most active biphenyl derivatives in inhibiting hTERT gene expression from HT-29 cell line; (b) Most active biphenyl derivatives in inhibiting $c-M y c$ gene expression from HT-29 cell line.

SAR for dual activity (anti-VEGF and anti-h-TERT)<smiles>CCCc1ccc(-c2ccccc2O)c(CCO)c1</smiles>

Figure 9. SAR studies for dual activity on biphenyl derivatives

Table 3. Honokiol and biphenyl derivatives with the highest activity in simultaneously inhibiting the expression of the $V E G F A, h T E R T$ and $c-M y c$ genes.

\begin{tabular}{|c|c|c|c|c|c|c|}
\hline \multirow[b]{2}{*}{ Comp. } & \multirow[b]{2}{*}{$\mathrm{IC}_{50}{ }^{\mathrm{a}}$} & \multirow[b]{2}{*}{$\alpha^{b}$} & \multirow[b]{2}{*}{$\begin{array}{l}\text { \% VEGFA } \\
\text { secretion }\end{array}$} & \multicolumn{3}{|c|}{$\%$ gene expression } \\
\hline & & & & $V E G F A$ & hTERT & $c-M y c$ \\
\hline HKL & 6.1 & 1.5 & 55 & 36 & 45 & 45 \\
\hline 3 & 2.5 & 23 & 57 & 23 & 3 & 18 \\
\hline 4 & 2.7 & 20 & 33 & 17 & 3 & 6 \\
\hline 15 & 2.5 & 28 & 50 & 5 & 29 & 16 \\
\hline 20 & 1.4 & 38 & 62 & 16 & 11 & 11 \\
\hline 26 & 3.4 & 9 & 52 & 35 & 30 & 39 \\
\hline
\end{tabular}

${ }^{\mathrm{a}} \mathrm{IC}_{50}$ values on HT-29 $(\mu \mathrm{g} / \mathrm{mL}) .{ }^{\mathrm{b}} \alpha=\mathrm{IC}_{50}(\mathrm{HEK}-293) / \mathrm{IC}_{50}(\mathrm{HT}-29)$

\section{Materials and Methods}

\subsection{Chemistry: general procedures}

General features. The signals of the deuterated solvent $\left(\mathrm{CDCl}_{3}\right.$ or $\left.\mathrm{CD}_{3} \mathrm{OD}\right)$ were taken as the reference. Multiplicity assignments of ${ }^{13} \mathrm{C}$ signals were made by means of the DEPT pulse sequence. High resolution mass spectra were run by the electrospray mode (ESMS). IR data were measured with oily films on $\mathrm{NaCl}$ plates (oils) or $\mathrm{KBr}$ pellets (solids) and are given only for molecules with relevant functional groups $(\mathrm{OH}, \mathrm{C}=\mathrm{O}$, $\mathrm{NH}_{2}$ ). Melting points are not corrected. Experiments which required an inert atmosphere were carried out under dry $\mathrm{N}_{2}$ in a flame-dried glassware. Commercially available reagents were used as received. Acronyms have been defined in Scheme 1.

\subsection{Reaction conditions}

\section{General Method A $\mathbf{A}^{28}$}

A mixture of the appropriate brominated arene $(1 \mathrm{mmol})$, the required boronic acid $(1.3 \mathrm{mmol})$ and $\mathrm{PdCl}_{2}(\mathrm{dppf}) \cdot \mathrm{CH}_{2} \mathrm{Cl}_{2}$ complex $(0.04 \mathrm{~g}$, ca. $0.05 \mathrm{mmol})$ were dissolved under an inert atmosphere in DME $(7 \mathrm{~mL})$. A $2 \mathrm{M} \mathrm{Na}_{2} \mathrm{CO}_{3}$ solution $(3 \mathrm{~mL})$ was then added, and the mixture was stirred at reflux until consumption of the starting materials (ca. 15-18 h, TLC monitoring). The mixture was poured into a separation funnel, diluted with water and extracted with ethyl ether $(4 \mathrm{x} 10 \mathrm{~mL})$. The combined organic layers were washed with brine. After desiccation over anhydrous $\mathrm{Na}_{2} \mathrm{SO}_{4}$, the volatiles were removed under reduced pressure. This afforded an oily material which was subjected to column chromatography on silica gel (hexaneEtOAc mixtures) to yield the desired biphenyl derivative.

\section{General Method B ${ }^{30}$}

The appropriate brominated arene $(1 \mathrm{mmol})$ was placed in a $10-\mathrm{mL}$ glass tube together with the corresponding boronic acid (1.3 mmol), $\mathrm{Pd}(\mathrm{OAc})_{2}(0.001 \mathrm{~g}$, ca. $0.005 \mathrm{mmol})$ and $\mathrm{Na}_{2} \mathrm{CO}_{3}$ (414 mg, $4 \mathrm{mmol}$ ) and a 1:1 ethanol/water mixture $(2 \mathrm{~mL})$. The mixture was stirred until homogeneity and the vessel was sealed with a septum, shaken, and placed into the microwave cavity. Microwave irradiation was initiated with a potency of $210 \mathrm{~W}$, the temperature being then increased from room temperature to 150 ${ }^{\circ} \mathrm{C}$. Once this value was reached, the reaction mixture was held at this temperature for $1 \mathrm{~h}$. After allowing the mixture to cool down to room temperature, the reaction vessel was opened and the mixture was poured into a separation funnel, diluted with water and extracted with ethyl ether $(4 \times 10 \mathrm{~mL})$. The combined organic layers were washed with brine. After desiccation over anhydrous $\mathrm{Na}_{2} \mathrm{SO}_{4}$, the volatiles were removed under reduced pressure. This afforded an oily material which was subjected to column chromatography on silica gel (hexane-EtOAc mixtures) to yield the desired biphenyl derivative.

\section{General Method C ${ }^{29}$}

A mixture of the appropriate brominated arene $(1 \mathrm{mmol})$, the required boronic acid $(1.3 \mathrm{mmol}), \mathrm{Pd}(\mathrm{OAc})_{2}(0.001 \mathrm{~g}$, ca. 0.005 mmol) and $\mathrm{Na}_{2} \mathrm{CO}_{3}(414 \mathrm{mg}, 4 \mathrm{mmol})$ was dissolved in a $1: 1$ ethanol/water mixture $(3 \mathrm{~mL})$. The mixture was then stirred at 70 ${ }^{\circ} \mathrm{C}$ until consumption of the starting materials (ca. $4 \mathrm{~h}$, TLC monitoring). The mixture was poured into a separation funnel, diluted with water and extracted with ethyl ether $(4 \times 10 \mathrm{~mL})$. The combined organic layers were washed with brine. After desiccation over anhydrous $\mathrm{Na}_{2} \mathrm{SO}_{4}$, the volatiles were removed 
under reduced pressure. This afforded an oily material which was subjected to column chromatography on silica gel (hexaneEtOAc mixtures) to yield the desired biphenyl derivative.

\section{General Method D ${ }^{29}$}

A mixture of the appropriate brominated arene $(1 \mathrm{mmol})$, the required boronic acid $(1.5 \mathrm{mmol}), \mathrm{Pd}(\mathrm{OAc})_{2}(1 \mathrm{mg}$, ca. 0.005 mmol) and $\mathrm{Na}_{2} \mathrm{CO}_{3}(212 \mathrm{mg}, 2 \mathrm{mmol})$ was dissolved in a $1: 1$ acetone/water mixture $(7 \mathrm{~mL})$. The mixture was then stirred at 35 ${ }^{\circ} \mathrm{C}$ until consumption of the starting materials (ca. $1 \mathrm{~h}$, TLC monitoring). The mixture was poured into a separation funnel, diluted with water and extracted with ethyl ether $(4 \times 10 \mathrm{~mL})$. The combined organic layers were washed with brine. After desiccation over anhydrous $\mathrm{Na}_{2} \mathrm{SO}_{4}$, the volatiles were removed under reduced pressure. This afforded an oily material which was subjected to column chromatography on silica gel (hexaneEtOAc mixtures) to yield the desired biphenyl derivative.

Yields and physical data are given in the Supplementary Data.

\subsection{Biological procedures}

\subsubsection{Reagents and cell culture}

Cell culture media were purchased from Gibco (Grand Island, NY, USA). Fetal bovine serum (FBS) was a product of HarlanSeralab (Belton, U.K.). Supplements and other chemicals not listed in this section were obtained from Sigma Chemicals Co. (St. Louis, Mo., USA). Plastics for cell culture were supplied by Thermo ScientificTM BioLite. All tested compounds were dissolved in DMSO at a concentration of $10 \mathrm{mg} / \mathrm{mL}$ and stored at $-20^{\circ} \mathrm{C}$ until use.

Cell lines were maintained in Dulbecco's modified Eagle's medium (DMEM) containing glucose $(1 \mathrm{~g} / \mathrm{L})$, glutamine $(2 \mathrm{mM})$, penicillin $(50 \mathrm{IU} / \mathrm{mL})$, streptomycin $(50 \mu \mathrm{g} / \mathrm{mL})$ and amphoterycin $(1.25 \mu \mathrm{g} / \mathrm{mL})$, supplemented with $10 \%$ FBS.

\subsubsection{Cytotoxicity assays}

The 3-(4,5-dimethylthiazol-2-yl)-2,5-diphenyltetrazolium bromide (MTT; Sigma Chemical Co., St. Louis, MO) dye reduction assay in 96-well microplates was used, as previously described. ${ }^{34}$ Some $5 \times 10^{3}$ cells of HT-29, MCF-7 or HEK-293 cells in a total volume of $100 \mu \mathrm{L}$ of their respective growth media were incubated with serial dilutions of the tested compounds. After 3 days of incubation $\left(37{ }^{\circ} \mathrm{C}, 5 \% \mathrm{CO}_{2}\right.$ in a humid atmosphere), $10 \mu 1$ of MTT ( $5 \mathrm{mg} / \mathrm{mL}$ in PBS) were added to each well and the plate was incubated for further $4 \mathrm{~h}\left(37^{\circ} \mathrm{C}\right)$. The resulting formazan was dissolved in $150 \mu \mathrm{L}$ of $0.04 \mathrm{~N} \mathrm{HCl} / 2$ propanol and read at $550 \mathrm{~nm}$. All determinations were carried out in triplicate.

\subsubsection{ELISA analysis}

HT-29 cells at $70-80 \%$ confluence were collected after serum starvation for $24 \mathrm{~h}$. Cells were incubated at the concentrations showed in Table 2 of the corresponding drugs in DMSO for $72 \mathrm{~h}$ (Fig. 3). Culture supernatants were collected and VEGFA protein secreted by HT-29 cells was determined using Invitrogen Human Vascular Endothelial Growth Factor ELISA Kit according to the manufacturer's instructions.

\subsubsection{RT-qPCR analysis}

HT-29 cells at $70-80 \%$ confluence were collected after serum starvation for $24 \mathrm{~h}$. Cells were incubated at the concentrations showed in Table 2 of the corresponding drugs in DMSO for $48 \mathrm{~h}$. Cells were collected and the total cellular RNA from HT-29 cells was isolated using Ambion RNA extraction Kit according to the manufacturer's instructions. The cDNA was synthesized by MMLV-RT with 1-21 $\mu \mathrm{g}$ of extracted RNA and oligo(dT)15 according to the manufacturer's instructions.

Amplification of the genes was performed by use of a StepOnePlus $^{\mathrm{TM}}$ thermalcycler. Fast TaqMan Gene Expression Master Mix containing the appropriate buffer for the amplification conditions, dNTPs, thermostable DNA polymerase enzyme and a passive reference probe was used. Each of the genes were amplified using predesigned primers by Life Technologies TaqMan ${ }^{\circledR}$ Gene Expression Assays, Hs99999903m1 ( $\beta$-actin), Hs00900055-m1 (VEGF), Hs00972646-m1 (hTERT) and Hs00153408-m1 (c-Myc).

\subsubsection{Statistical analysis}

Data are expressed as the mean \pm SEM. Statistical analyses were done using Microsoft Excel and GraphPad Prism ${ }^{\circledR}$. Differences between means were determined using one-way ANOVA with Dunnett's Multiple Comparison Test, and considered to be statistically significant at $\alpha \leq 0.05$.

\section{Acknowledgments}

Financial support has been granted to M.C. by the Ministerio de Economía y Competitividad of Spain (project CTQ201452949-P), by the Consellería d'Empresa, Universitat i Ciencia de la Generalitat Valenciana (projects PROMETEO/2013/027 and ACOMP/2014/ 274) and by the University Jaume I (project PI1B2011-37). M. S.-P. thanks the University Jaume I for a predoctoral fellowship. We thank Rafael Pulido for providing HT-29 cells.

\section{References and notes}

1. Takeshita, F.; Ochiya, T. Cancer Sci. 2006, 97, 689-696.

2. Leung, R. K.; Whittaker, P. A. Pharmacol Ther. 2005, 107, 222-239.

3. Reicht, S. J.; Fosnot, J.; Kuroki, A.; Tang, W.; Yang, X.; Maguire, A. M. Mol. Vis. 2003, 9, 210-216.

4. Carmeliet P. Nature 2000, 407, 249-257.

5. Robinson, C. J.; Stringer, S. E. J. Cell Sci. 2001, 114, 853-865.

6. Arora, S.; Kaur, J.; Sharma, C.; Mathur, M.; Bahadur, S.; Shukla, N. K. Clin. Cancer Res. 2005, 11, 2272-2284.

7. Wai, L. K. Med. Gen. Med. 2004, 6, 19.

8. (a) Chen, S. M; Tao, Z. Z.; Hua, Q. Q. Arch. Otolaryngol Head Neck Surg 2006, 132, 200-2005; (b) Shay, J.W. Nat. Rev. Drug Discov 2006, 5, 577-584.

9. Land, H.; Parada, L. F.; Weinberg, R. A. Nature 1983, 306, 194-196.

10. Mariani-Constantini, R.; Escot, C.; Theillet; C. Cancer Res. 1988, 48, 199-205.

11. Augenlicht, L. H.; Wadler, S.; Corner, G. Cancer Res. 1997, 57, 1769-1775.

12. Terasawa, K.; Sagae, S.; Takeda, T.; Ishioka, S.; Kobayashi, K.; Kudo, R. Cancer Lett 1999, 142, 207-217.

13. (a) Ali, M. A.; Choy, H.; Habib, A. A.; Saha, D. Neoplasia 2007, 9, 370-381. (b) Juo, H.; Jiang, B. H.; King, S. M.; Chen, Y. C. Nutr. Cancer 2008, 60, 800-809. (c) Furumai, R.; Uchida, K.; Komi, Y.; Yoneyama, M.; Ishigami, K.; Watanabe, H.; Kojima, S.; Yoshida, M. Cancer Sci. 2010, 101, 2483-2489. (d) Wang, L.; Zeng, Y.; Wang, T.; Liu, H.; Xiao, H.; Xiang H. PLoS One 2014, 9, e86509. (e) Sreenivasalu, K.; 
Vijayalakshmi, M. International $J$ Biotechnology and Biochemistry 2010, 6, 109-166. (f) Chen, Y. Y.; Wu, X. Q.; Tang, W. J.; Shi, J. B.; Li, J.; Liu, X. H. Eur. J. Med. Chem. 2014, 110, 65-75. (g) Vilanova, C.; Díaz-Oltra, S; Murga, J.; Falomir, E.; Carda, M, Marco, J. A. Bioorg. Med. Chem. Lett. 2015, 25, 3194-3198. (h) Martí-Centelles, R.; Murga, J.; Falomir, E.; Carda, M, Marco, J. A. Med. Chem. Comm. 2015, 6, 1809-1815. (i) Martí-Centelles, R.; Falomir, E.; Murga, J.; Carda, M, Marco, J. A. Eur. J. Med. Chem. 2015, 103, 488496.

14. Aldemir, H.; Richarz, R.; Gulder, T. A. M. Angew. Chem. Int. Ed. 2014, 53, 8286-8293.

15. Zhang, J.; Chen, J.; Liang, Z.; Zhao, C. Chem. Biodivers. 2014, 11, 1-54.

16. Shen, J.-L.; Man, K.-M.; Huang, P.-H.; Chen, W.-C.; Chen, D.C.; Cheng, Y.-W.; Liu, P.-L.; Chou, M.-C.; Chen, Y.-H. Molecules 2010, 15, 6452-6465.

17. Lee, Y.-J.; Lee, Y. M.; Lee, C.-K.; Jung, J. K.; Han, S. B.; Hong, J. T .Pharmacol. Ther. 2011, 130, 157-176.

18. For a recent interesting review on natural product analogs: Maier, M. E. Org. Biomol. Chem. 2015, 13, 5302-5343.

19. See, for example: Vilanova, C.; Díaz-Oltra, S.; Murga, J.; Falomir, E.; Carda, M.; Redondo-Horcajo, M.; Díaz, J. F.; Barasoain, I.; Marco, J. A. J. Med. Chem. 2014, 57, 1039110403, and references to previous work cited therein.

20. The Role of Microtubules in Cell Biology, Neurobiology and Oncology, (Ed. T. Fojo), Humana Press, Totowa, New Jersey, 2008.

21. Moserle, L.; Jiménez-Valerio, G.; Casanovas, O. Cancer Discov. 2014, 4, 31-41

22. Bernardes de Jesus, B.; Blasco, M. A. Trends Genet. 2013, 29, 513-520.

23. Hoelder, S.; Clarke, P. A.; Workman, P.Mol. Oncol. 2012, 6, 155-176.

24. Han, C.; Zhang, J.; Zheng, M.; Xiao, Y.; Li, Y.; Liu, G. Mol. Divers. 2011, 15, 857-876.

25. Hassan, J.; Sévignon, M.; Gozzi, C.; Schulz, E.; Lemaire, M. Chem. Rev. 2002, 102, 1359-1469.

26. Ashenhurst, J. A. Chem. Soc. Rev. 2010, 39,540-548.

27. Lennox, A. J. J.; Lloyd-Jones, G. C. Chem. Soc. Rev. 2014, 43, 412-443.

28. Tripathi, S.; Chan, M.-H.; Chen, C. Bioorg. Med. Chem. Lett. 2012, 22, 216-221.

29. Liu, L.; Zhang, Y.; Xin, B. J. Org. Chem. 2006, 71, 3994-3997.

30. Leadbeater, N. E.; Marco, M. Org. Lett. 2002, 4, 2973-2976.

31. (a) Van Weemen, K. V.; Schuurs, A. H. W. M. FEBS Lett. 1971, 15, 232-236. (b) Engvall, E.; Perlmann, P. J. Immunol. 1972, 109, 129-135. (c) O'Beirne, A. J.; Cooper, H. R. J. Hystochem. Cytochem. 1979, 27, 1148-1162.

32. Bustin, S. A.; Benes, V.; Garson, J. A.; Hellemans, J.; Huggett, J.; Kubista, M.; Mueller, R.; Nolan, T.; Pfaffl, M. W.; Shipley, G. L.; Vandesompele, J.; Wittwer, C. T. Clin. Chem. 2009, 55, 611-622.

33. (a) Luo, H.; Jiang, B.-H.; King, S. M.; Chen, Y. C. Nutrition and Cancer 2008, 60, 800-809. (b) Hollborn, M.; Stathopoulos, C.; Steffen, A.; Wiedermann, P.; Kohen, L.; Bringmann, A. Investigative Ophtalmology and Visual Science 2007, 48, 4360-4367.

34. Rodríguez-Nieto, S.; Medina, M. A.; Quesada, A. R. Anticancer Res. 2001, 21, 3457-3460. 